\title{
The effects of tuber size and chitting method on the growth and yield of Amyla and Barima potatoes
}

\author{
EERO VARIS \\ Plant Breeding Institute of Hankkija, \\ Experimental Farm Anttila, Hyrylä, Finland
}

Received March 23, 1973

\begin{abstract}
The effects of two seed tuber sizes on the growth and the yield of the potato when using various methods of chitting were studied in 1963-66. The cultivars used were Amyla and Barima.

The variations affected by seed size were not directly proportional to the seed weight. From small seed the early development of the haulms was slower, the number of stems smaller, the weight of the haulms and roots smaller. The number of tubers per hill was lower but the number of tubers per stem higher. Average yield per seed tuber was 16 per cent smaller. Small seed produced a slightly higher starch content and a lower percentage of blight infected tubers.

Plants from large seed tubers developed faster and the weight of their haulms and roots declined more in the autumn. In the early liftings also the tuber yield per hill was distinctly larger than from small seed, but in the case of the earlier cultivar Barima the difference was fully levelled out by the autumn.

Chitting made the early growth faster, decreased the number of stems, reduced the weight of the haulms and roots and decreased the number of tubers per hill. The average increases of yield and starch content were not significant but were dependent on cultivar and lifting time. When chitting was employed the amount of large tubers increased and scab infection decreased.

In many respects Amyla and Barima reacted differently both to seed tuber size and to chitting.
\end{abstract}

\section{Introduction}

In potato production, seed accounts for a large part of the total production costs. Therefore there has been a general tendency to look for ways of reducing seed costs either by reducing the seed rate or by decreasing the seed size (Roer 1955, Bleasdale 1965, Holmes 1966, Janda 1970, Svensson and CARLsson 1972). In the USA the same result is aimed at by using cut seed (TINGEy and Stewart 1928, French 1958). In order to investigate the effects of seed size under Finnish conditions a trial series was arranged at the Hankkija 
Plant Breeding Institute, Experimental Farm Anttila, during 1963-66. In the trials the effect of two seed sizes on the development of plants and the yield of two potato varieties were studied. Chitting was included in order to establish its importance when seed of different sizes was employed.

\section{Materials and methods}

The experiment design used was a polyfactorial block trial where the treatments were as follows:
A. Year 1963
1964
1965
1966
B. Cultivar 1. Amyla, early maincrop, many tubers
2. Barima, first early, few tubers
C. Seed size 1. Large, about $90 \mathrm{~g}$
2. Small, about $40 \mathrm{~g}$
D. Chitting 1. Not chitted
2. Chitted in dark
3. Chitted in light
4. Chitted in perforated plastic bags
E. Time of lifting 1. 60 days from planting
2. 80 days
3. 120 days

Seed was selected by sorting: large size $40-55 \mathrm{~mm}$ and small size $35-40$ $\mathrm{mm}$. Selection was checked by hand. The unchitted seed was kept in a cold store (about $+5^{\circ} \mathrm{C}$ ) until planting. The chitted seeds were kept for four to six weeks in a warm light store, where the temperature was $+12-+16^{\circ} \mathrm{C}$ and the relative humidity $80-90 \%$. Open boxes were used for the seed chitted in light, for the dark chitted seed the boxes were covered with thick paper. For chitting in plastic bags perforated transparent $10 \mathrm{~kg}$ plastic bags were hung from the middle on a rod (RAIDT 1961).

The planting dates were as follows:

\begin{tabular}{|c|c|}
\hline $1963 \ldots \ldots . .$. & May 23 \\
\hline 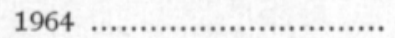 & May 24 \\
\hline 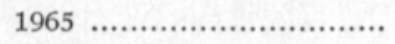 & May 23 \\
\hline 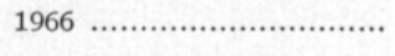 & May 20 \\
\hline
\end{tabular}

The trial site consisted of fertile clay soil rich in humus. It was dressed with normal amounts of a compound fertilizer recommended for potato.

In order to reduce sprout loss the planting was done by hand in holes made with a tractor-driven dibbler. Row spacing was $65 \mathrm{~cm}$, tuber spacing $30 \mathrm{~cm}$. Each plot consisted of 25 tubers in one row. The harvesting was done by 
hand. The haulms were first cut to ground level. The part of the roots that came up in the lifting was regarded as root mass.

The following observations were recorded:

1. Weight loss of seed tubers. The tubers were weighed before and after chitting and the percentage weight loss was calculated.

2. Number of sprouts. Before planting, the number of viable sprouts in the chitted seed lots was counted.

3. Early development of the haulms. About two weeks after emergence the growth rate was evaluated by means of a scale from $0-100(0=$ emerging, $100=$ maximum growth).

4. and 5. Number of stems and tubers. In connection with the liftings the numbers of stems and tubers were counted.

6., 7., and 8. Weight of haulms, roots and tubers. In connection with the liftings the haulm, root and tuber yields were determined.

9. Proportion of large tubers. The yield was sorted into two sizes by using a $30 \mathrm{~mm}$ riddle. Tubers over $30 \mathrm{~mm}$ were regarded as large.

10. Starch content. The starch content was measured on a $5 \mathrm{~kg}$ sample by means of Reimann's scales and Hals \& Buchholtz's tables.

11. Tuber blight. Blight infected tubers were separated from the same $5 \mathrm{~kg}$ sample and their portion of the total sample was determined by weighing.

12. Scab. Scab infection was recorded by using a $0-100$ scale $(0=$ no scab, $100=$ fully scabbed).

Results were calculated at the EDP Department of Keskusosuusliike Hankkija employing a programme ANOV GE-400 Series. The statistical significance of the results is expressed as follows:

$\begin{aligned} * * * & =99.9 \% \text { significance } \\ * * & =99 \% \\ * & =95 \quad \% \\ \left({ }^{*}\right) & =90 \quad \% \\ \mathrm{~ns} & =\text { not significant }\end{aligned}$

A report of the prevailing weather conditions of the years concerned is printed for instance in Siemenjulkaisu 1965 and 1970 (KIVI and VARIs 1965, REKUNEN 1970).

Results

The results of the analysis of variance are presented in Table 1 .

Seed tubers

According to the analysis of variance the seed weight was significantly different between tuber sizes but not between methods of chitting (Tables 1 and 2).

The seed sizes of the treatments varied slightly from year to year (interactions year $\times$ cultivar, year $\times$ seed size, and year $\times$ cultivar $\times$ seed size). In addition, the large tubers of Barima were larger than those of Amyla (Amyla 85 and $35 \mathrm{~g}$, Barima 94 and $34 \mathrm{~g}$ ). However, the difference prevalent in the 


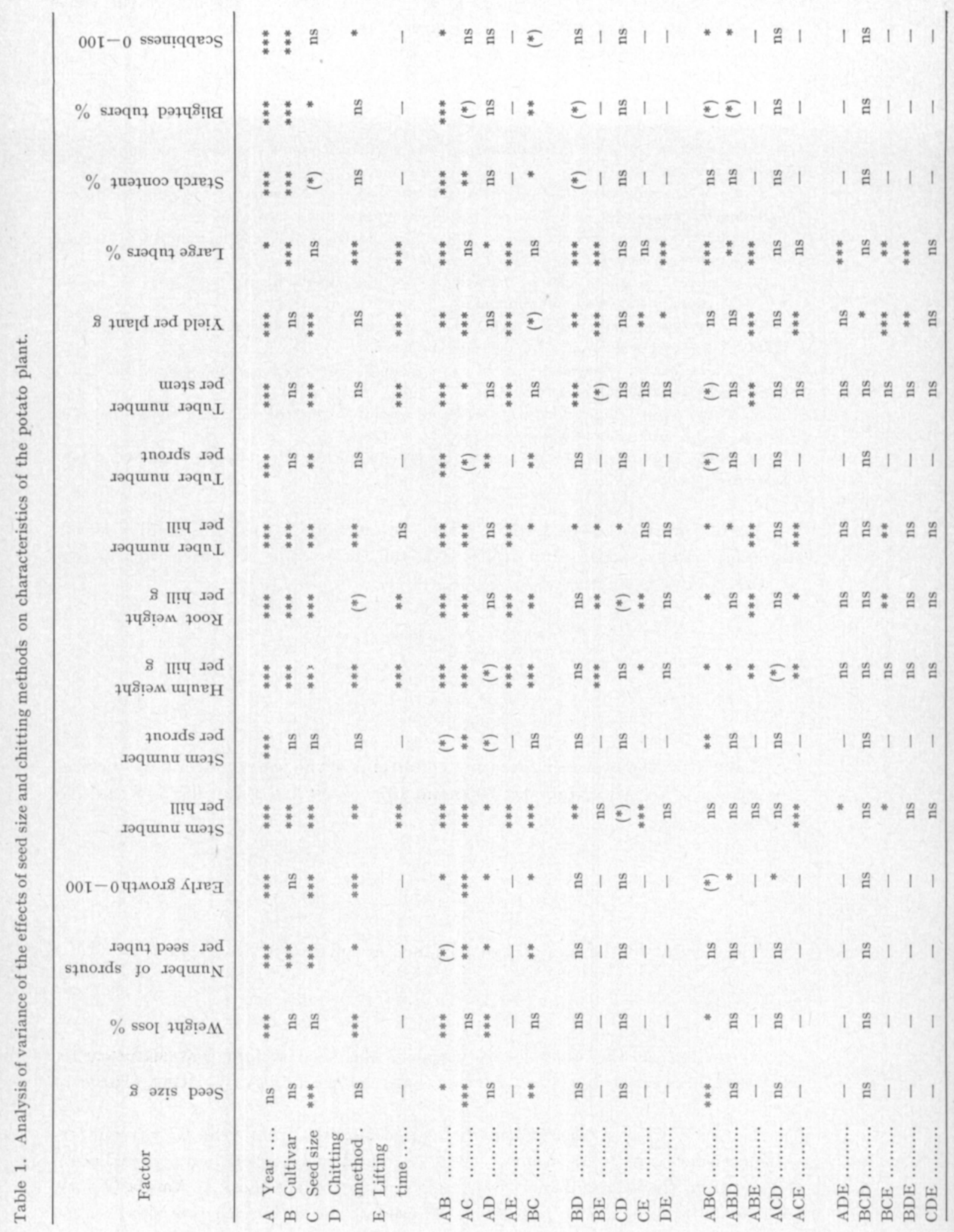


Table 2. Seed tuber weight.

\begin{tabular}{|c|c|c|c|}
\hline \multirow[b]{2}{*}{ Chitting method } & \multicolumn{3}{|c|}{ Seed tuber weight $g$} \\
\hline & $\begin{array}{l}\text { Large } \\
\text { seed }\end{array}$ & $\begin{array}{l}\text { Small } \\
\text { seed }\end{array}$ & Average \\
\hline Not chitted .............................. & 92 & 35 & 64 \\
\hline In dark ............................... & 90 & 34 & 62 \\
\hline 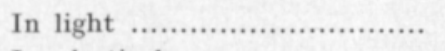 & 88 & 35 & 61 \\
\hline In plastic bags $\ldots \ldots \ldots \ldots \ldots \ldots \ldots$ & 88 & 34 & 61 \\
\hline $\begin{array}{l}\text { Average } \\
\text { LSD } 5 \% \text { Seed size } 8\end{array}$ & 89 & 34 & 62 \\
\hline
\end{tabular}

main effect between seed sizes was always distinct. The annual variations were caused by the fact that the seed for the experiment had to be adapted to the tuber size distribution of the available seed lots.

Weight loss

The weight loss during chitting was determined by weighing the seed lots before and after chitting (Table 3 ).

Table 3. Weight loss caused by chitting in different seed size classes.

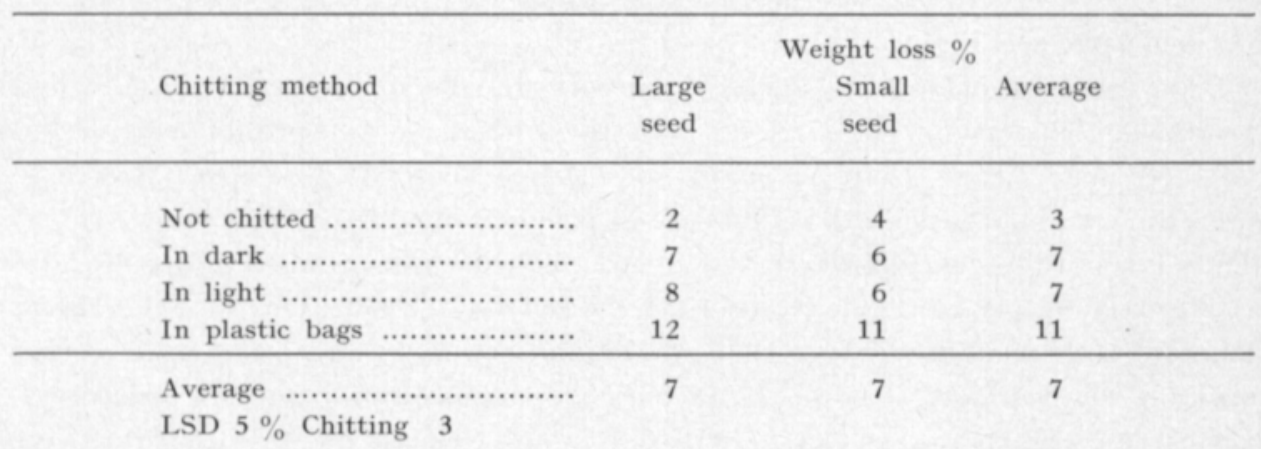

Chitting increased the weight loss considerably, the heaviest loss occurring when a plastic bag method was applied (Tables 1 and 3). The average weight loss was equal in both seed sizes and in both cultivars.

The weight loss varied annually between $4-11 \%$. Annual variation appeared differently in different treatments, as seen in the interactions year $\times$ cultivar, year $\times$ chitting and also in year $\times$ cultivar $\times$ seed size. Differences were caused by yearly variations in chitting conditions. 
Number of sprouts

Before planting the number of viable sprouts on chitted lots was counted (Table 4).

Table 4. Sprout numbers in different chitting methods.

\begin{tabular}{|c|c|c|c|}
\hline \multirow{2}{*}{ Chitting method } & \multicolumn{3}{|c|}{ Sprout number per seed tuber } \\
\hline & Large seed & Small seed & Average \\
\hline 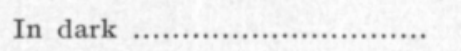 & 8.7 & 5.5 & 7.1 \\
\hline 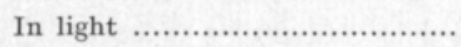 & 7.1 & 4.9 & 6.0 \\
\hline In blastic bags .................... & 7.7 & 4.7 & 6.2 \\
\hline $\begin{array}{l}\text { Average } \\
\text { LSD } 5 \% \text { Seed size } 0.7 \quad \text { Chitti }\end{array}$ & $\begin{array}{r}7.8 \\
\text { ting } 0.9\end{array}$ & 5.0 & 6.4 \\
\hline
\end{tabular}

There were significantly more sprouts in large seed (cf. TINGEY and STEWart 1928, Roer 1955, Toosey 1962, Birecki and Roztropowicz 1963, Bleasdale 1965, Dent and Halkon 1969). Chitting in darkness produced more sprouts than other methods of chitting. The interaction effect seed size $\times$ chitting was not significant. The number of sprouts varied annually (3.89.7) and was dependent on the cultivar (Amyla 7.4, Barima 5.4) (cf. Svensson 1966). There appeared to be annual variation in the number of sprouts in all treatments. Only in case of the chitting method did the annual variation clearly differ from the trend of the main effect: darkness chitting produced distinctly more sprouts only in two years out of four. The difference in the number of sprouts between Amyla and Barima was bigger with large seed tubers (cultivar $\times$ seed size, see Figure 1).

The number of sprouts plays an important role in determing the yield producing capacity of seed tubers. In these trials more sprouts were found on large seed tubers than on small ones $(89 \mathrm{~g}-7.8,34 \mathrm{~g}-5.0)$. However, the number of sprouts did not decrease in proportion to the weight of the tuber. Thus when tuber weight decreased by 62 per cent the number of sprouts did so by only 36 per cent (cf. Roer 1955, Bleasdale 1965). On the other hand Birecki and Roztropowicz (1963) in Poland found fewer sprouts per weight unit on small tubers than on large ones. The number of sprouts on Amyla, a cultivar with many sprouts, increased more with an increase in tuber size than on Barima, a cultivar of few sprouts, (Amyla $40 \%$, Barima $31 \%$ ) (Figure 1).

In Figure 1 the relationship between seed size and number of sprouts has not been assumed linear (cf. Bleasdale 1965, Dent and Halkon 1969), but to follow the formula $y=\sqrt[a]{x}$, ie. a parabola which goes through the origin. According to this hypothesis the number of sprouts increases rapidly with seed size in the beginning, but slows down later on. Bleasdale (1965) used another kind of formula, with similar results in practice, however. In case of Amyla and Barima the constant a was almost equal (2.7 and 2.8), therefore 


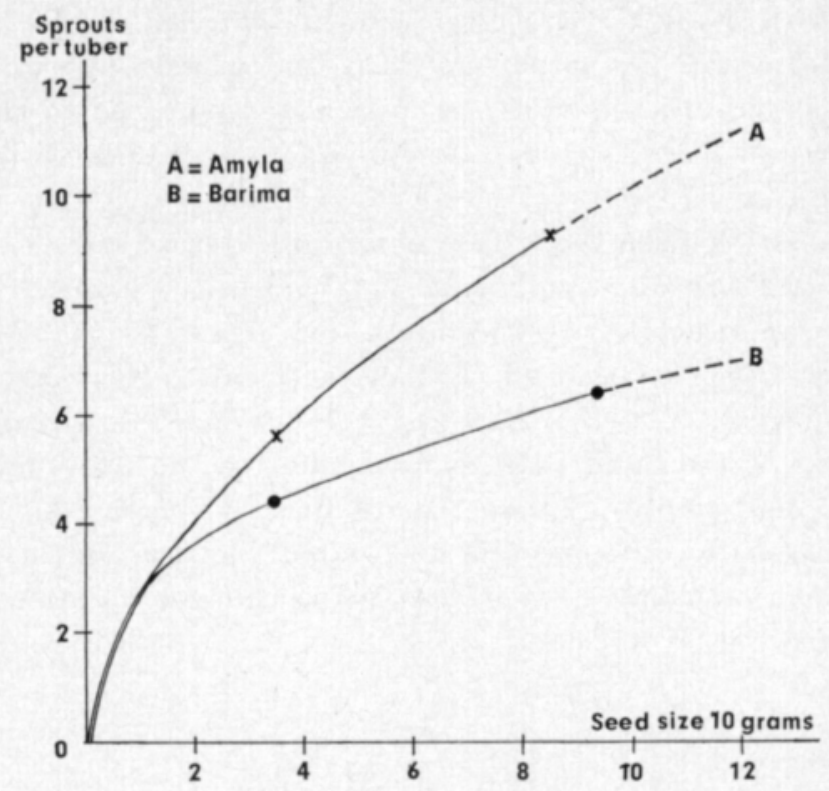

Figure 1. The relation of number of sprouts to seed tuber size.

$$
\begin{array}{ll}
\text { Amyla } & y=2.7 \sqrt[1.75]{x} \\
\text { Barima } & y=2.8 \sqrt[2.71]{x}
\end{array}
$$

also a general formula could be employed $y=2.8 \sqrt[n]{x}$ or in logarithmic form $\log \mathrm{y}=0.44716+\frac{\log \mathrm{x}}{\mathrm{n}}$, where $\mathrm{n}$ is a constant varying annually and depending on the cultivar.

Early development of the haulms

The rate of early growth of the haulms was dependent on both tuber size and method of chitting (Tables 1 and 5).

\begin{tabular}{|c|c|c|c|}
\hline \multirow{2}{*}{ Chitting method } & \multicolumn{2}{|c|}{ Early growth $0-100$} & \multirow[b]{2}{*}{ Average } \\
\hline & Large seed & Small seed & \\
\hline Not chitted ....................... & 36 & 31 & 33 \\
\hline 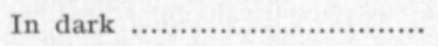 & 48 & 38 & 43 \\
\hline In light ............................... & 52 & 42 & 47 \\
\hline In plastic bags ...................... & 50 & 42 & 46 \\
\hline $\begin{array}{l}\text { Average } \\
\text { LSD } 5 \% \text { Seed size } 3 \text { Chitting }\end{array}$ & 46 & 38 & 42 \\
\hline
\end{tabular}

Table 5. Early growth of potato plants $(0=$ slow, $100=$ fast $)$. 
Large tubers had a faster early development, which probably was due to the larger nutritive reserve per sprout (MoorBy 1967). All chittings accelerated development, as did efficient chittings in light as compared to chitting in the dark (cf. KRUG and Pätzold 1968). The interaction effect seed size $\times$ chitting was not significant.

Differences between the years were significant as expected. The interaction effect year $\times$ seed size was significant, the trend of the main effect, however, remaining the same each year. The interaction effect year $\times$ chitting showed slight variation primarily between chitted treatments. There was a difference between the cultivars in two years. Also the interaction cultivar $\times$ seed size was significant and indicated that seed size affected the early development of Amyla less (47 and 40,15\%) than that of Barima (46 and 36, $22 \%$ ) which might indicate genetic differences in the viability of the sprouts. Also some second order interaction effects were observed, the annual variation being always present in these.

\section{Number of stems}

The stems were counted in each lifting. Both seed size and chitting method affected the number of stems (Tables 1 and 6).

Table 6. Stem numbers (averages of three liftings).

Chitting method

Stem number per hill

Large seed Small seed Average

\begin{tabular}{|c|c|c|c|}
\hline Not chitted ....................... & 8.2 & 5.1 & 6.6 \\
\hline 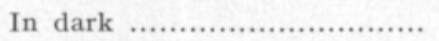 & 7.6 & 4.7 & 6.2 \\
\hline 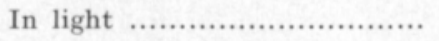 & 7.2 & 4.6 & 5.9 \\
\hline In plastic bags .................... & 7.3 & 4.9 & 6.1 \\
\hline Average & 7.6 & 4.8 & 6.2 \\
\hline
\end{tabular}

As expected more stems emerged from large tubers (cf. TIngEY and STEwart 1928, Roer 1955, Svensson 1961, Toosey 1962, Bleasdale 1965 , DENT and HALKon 1969). Likewise, unchitted tubers produced more stems than chitted ones. According to BIREcki and Roztropowicz (1963) large tubers produced more stems per weight unit than small ones, which result differs from the one found here.

The interaction effect of seed size $\times$ chitting was slightly significant indicating that when large tubers were chitted the number of stems decreased more than with small tubers. If the aim is the largest possible number of stems per seed tuber, efficient sprouting of large tubers seems less advisable. When the number of stems is compared with the number of sprouts it will be observed that in the case of chitting in darkness the sprouts have apparently been damaged during planting in spite of the careful handling. 
There were more stems on Amyla than on Barima (7.3 and 5.0). The annual differences were also considerable $(5.1-7.1)$ but not as great as in the number of sprouts. The number of stems decreased towards the end of the growing season $(6.6-6.4-5.5)$. Among the first order interaction effects there were several significant ones, i.e. all where the factor year was included. Regarding tuber size the result was each year similar to the trend of the main effect, regarding chitting method the difference seen in the main effect was significant in three years out of four. Each year Amyla produced more stems than Barima. The number of stems also decreased each year during the growing season, although there were differences in timing.

The cultivars reacted differently to seed size and chitting. The stem number of Amyla depended distinctly more on seed size than that of Barima (Amyla 9.0 and 5.6, $38 \%$, Barima 6.1 and $4.0,34 \%$ ), see "Number of sprouts». The stem number of Amyla decreased only when chitting in daylight was applied, those on Barima decreased in all chitting methods showing that Barima was more disposed towards single-sprout formation.

Some second order interaction effects were also noted.

If the number of stems is presumed to change in the same way as the number of sprouts as functions of seed size, the curves shown in Figure 2 are obtained.

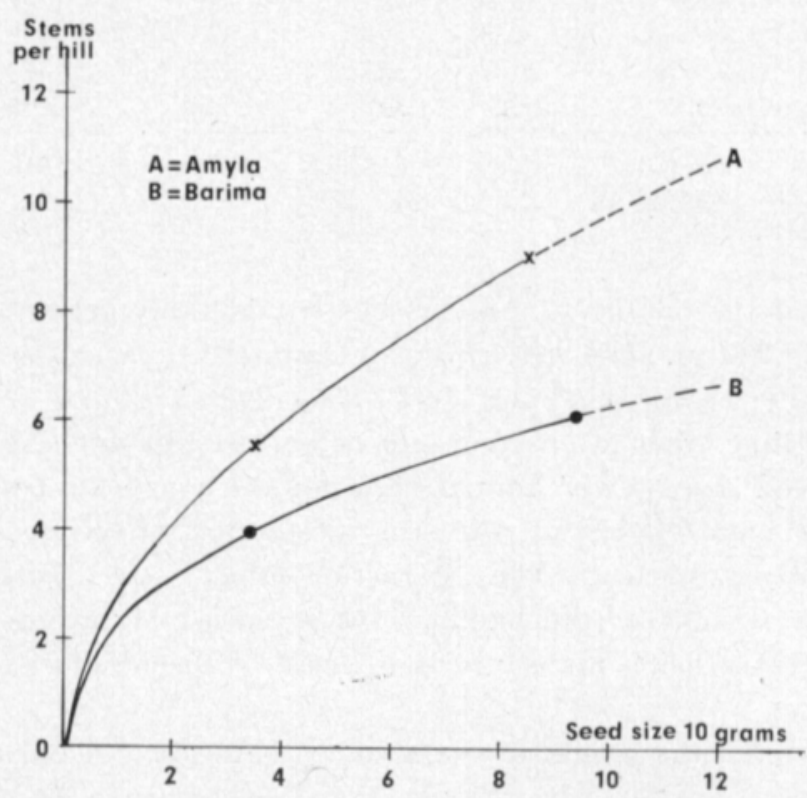

Figure 2. The relation of number of stems to seed tuber size.

$$
\begin{array}{ll}
\text { Amyla } & y=2.8 \sqrt[1.85]{x} \\
\text { Barima } & y=2.4 \sqrt[2.41]{x}
\end{array}
$$

There was a marked difference in stem number between the cultivars. 
When relating the number of stems to that of sprouts a positive correlation $\mathrm{r}=+\mathbf{0 . 7 6 * * *}$ was obtained. The number of stems per sprout was on anerage 1.0 (cf. Moorby 1967). Mainly annual variation was observed $(0.8-1.4)$ (Table 1).

Weight of the haulms

The weight of the haulms was determined in each lifting. It varied depending on seed size and chitting (Tables 1 and 7) (cf. RoER 1955, KRUG and PätzolD 1968, DAмвroth and Pätzold 1969). The weight of the haulms of large and small tubers varied in the same way with all the chitting methods.

Table 7. Haulm weight (averages of three liftings).

\begin{tabular}{|c|c|c|c|}
\hline Chitting method & $\begin{array}{l}\text { Stem } \\
\text { Large seed }\end{array}$ & $\begin{array}{l}\text { weight per } \\
\text { Small seed }\end{array}$ & $\begin{array}{l}\text { hill } \\
\text { Average }\end{array}$ \\
\hline Not chitted ........................ & 395 & 306 & 350 \\
\hline 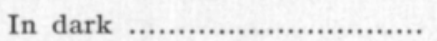 & 352 & 277 & 315 \\
\hline In light .............................. & 358 & 262 & 310 \\
\hline In plastic bags $\ldots \ldots \ldots \ldots \ldots \ldots \ldots$ & 327 & 264 & 295 \\
\hline $\begin{array}{l}\text { Average ................................... } \\
\text { LSD } 5 \% \text { Seed size } 18 \quad \text { Chitti }\end{array}$ & $\lg 26$ & 277 & 318 \\
\hline
\end{tabular}

The weight of the haulms of Amyla was considerably greater than that of Barima (423 and $212 \mathrm{~g}$ ). The weight of the haulms also varied annually (261$422 \mathrm{~g})$ and at different lifting times $(304-357-292 \mathrm{~g})$.

Most of the first order interaction effects were significant. The interaction effect year $\times$ seed size showed annual variation, although always in the same direction as the main effect, as did the interaction effects year $\times$ cultivar and year $\times$ chitting method. The interaction effect year $\times$ lifting time also showed that the weight of the haulms always varied according to the main effect, the difference being mainly in the degree of the weight decrease in the third lifting.

Seed size affected the weight of the haulms of Amyla and Barima such that the difference was greater with Amyla than with Barima (Amyla 477 and $369 \mathrm{~g}$, Barima 239 and $185 \mathrm{~g}$ ), although the percentage of the difference was equal at $23 \%$.

The weight of Amyla haulms decreased less in the autumn (Amyla 372-454 -443 , Barima $234-259-149$ ). This was apparently due to the difference in earliness between the cultivars. The chitting method affected the development of the haulms of both cultivars in a similar way. However, the weight of the haulms from large seed decreased faster in autumn than the one from small seed (seed size $\times$ lifting time) (Figure 3 ). 


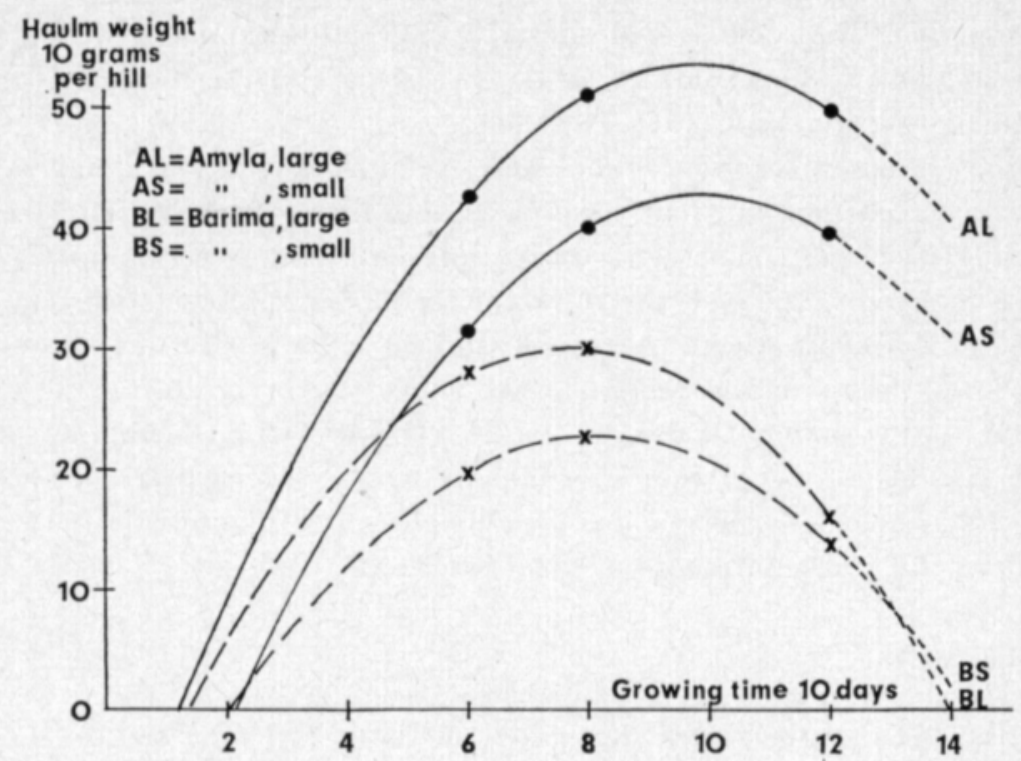

Figure 3. The relation of growth rhythm of the potato plants to seed size.
AL $y=-16.7+14.3 x-0.73 x^{2}$
AS $\mathrm{y}=-27.3+14.1 \mathrm{x}-0.71 \mathrm{x}^{2}$
BL $\mathrm{y}=-14.1+11.5 \mathrm{x}-0.75 \mathrm{x}^{2}$
BS $\mathrm{y}=-19.3+10.2 \mathrm{x}-0.62 \mathrm{x}^{2}$

Possibly this is due to the difference in maturing time caused partly by the different stem density and partly by a real physiological difference in earliness.

Some of the second order interaction effects were likewise significant, mainly as an indication of the annual variations.

\section{Weight of the roots}

The weight of the roots was also determined during the liftings. It varied according to seed size and method of chitting (Tables 1 and 8 ). The decrease in the weight of the roots caused by chitting was greater when large seed was used (seed size $\times$ chitting method).

Table 8. Root weight (averages from three liftings).

\begin{tabular}{|c|c|c|c|c|}
\hline & Chitting method & $\begin{array}{l}\text { Root weig } \\
\text { Large seed }\end{array}$ & $\begin{array}{l}\text { per hill } \\
\text { Small seed }\end{array}$ & Average \\
\hline \multirow{4}{*}{$>$} & Not chitted .......................... & 91 & 58 & 74 \\
\hline & 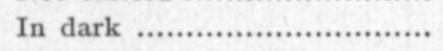 & 79 & 50 & 65 \\
\hline & In light ................................ & 80 & 51 & 65 \\
\hline & 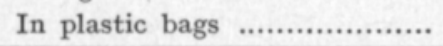 & 76 & 55 & 66 \\
\hline & 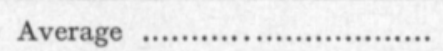 & 82 & 54 & 68 \\
\hline
\end{tabular}


The weight of the roots varied annually $(53-110 \mathrm{~g})$ and was dependent on the cultivar (Amyla $80 \mathrm{~g}$, Barima $55 \mathrm{~g}$ ). The weight of the roots also changed during the growing season $(61-76-66 \mathrm{~g})$.

The first order interaction effects were often significant. Annual variation was observed regarding cultivar, seed size, and lifting time but the trend of the main effect was, however, always present. The weight of the roots of Amyla changed more with the different seed sizes, always, however, within the frame of the main effects (Amyla 97 and $63 \mathrm{~g}, 35 \%$, Barima 66 and $44 \mathrm{~g}$, $33 \%$ ). The decrease in the weight of the roots of Amyla during the growing season was slower than with Barima (Amyla $69-88-83 \mathrm{~g}$, Barima $52-63-50$ g). Seed size also affected the development of the weight of the roots (large 75-93-76 g, small $46-58-57 \mathrm{~g}$ ), see "Weight of the haulms».

Some second order interaction effects were also recorded.

Number of tubers

The number of tubers was dependent on both the seed size (cf. Toosey 1962, DAmbroth and Pätzold 1969) and the method of chitting (cf. KRUG and PÄtzold 1968) (Tables 1 and 9). The interaction effect seed size $\times$ chitting was also significant indicating bow chitting reduced especially the number of tubers when large seed tubers were used (cf. DAмвroth and Pätzold 1969) (Table 9).

Table 9. Tuber number (averages of three liftings).

\begin{tabular}{|c|c|c|c|}
\hline Chitting method & $\begin{array}{c}\text { Tuber } \\
\text { Large seed }\end{array}$ & $\begin{array}{l}\text { number per } \\
\text { Small seed }\end{array}$ & $\begin{array}{l}\text { hill } \\
\text { Average }\end{array}$ \\
\hline 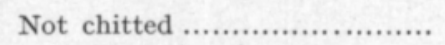 & 15.6 & 11.7 & 13.6 \\
\hline 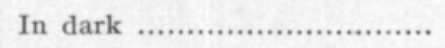 & 13.3 & 10.1 & 11.7 \\
\hline 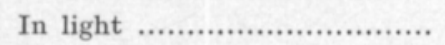 & 12.4 & 10.1 & 11.3 \\
\hline In plastic bags .................... & 12.3 & 10.2 & 11.2 \\
\hline Average & 13.4 & 10.5 & 12.0 \\
\hline
\end{tabular}

The number of tubers varied annually $(9.9-16.0)$ and was dependent on the cultivar (Amyla 14.2, Barima 9.7). The number of tubers did not vary significantly during the growing season.

Almost all main effects varied annually, but the trend of the main effect remained, however, in most cases.

From the interaction effect cultivar $\times$ seed size it can be seen that the number of tubers of Amyla varied more than that of Barima with the different seed sizes (Amyla 15.9 and 12.5, $21 \%$, Barima 10.9 and 8.5, $22 \%$, see page 305$)$, although the relative change was equal. Also chitting reduced the number of tubers of Amyla more than that of Barima, a result which did not fully correlate with the number of stems (page 305). The number of tubers of Barima was less at the last lifting.

Several of the second order interaction effects were significant. 
When the numbers of tubers are compared with the numbers of sprouts or stems, a distinct similarity is found to exist. To clarify this the ratios tuber number per sprout and tuber number per stem and the corresponding correlations were calculated.

There was a positive correlation $\mathrm{r}=+\mathbf{0 . 5 4 * * *}$ between the numbers of sprouts and tubers in which, however, relatively large deviations could be found. According to analysis of variance the ratio between sprouts and tubers varied depending on the size of the seed but not on the method of chitting (Tables 1 and 10). Annually the ratio varied considerably $1.2-2.6$. The ratio

Table 10. Tuber number per sprout.

\begin{tabular}{|c|c|c|c|}
\hline Chitting method & $\begin{array}{r}\text { Tuber } \\
\text { Large seed }\end{array}$ & $\begin{array}{l}\text { number per } \\
\text { Small seed }\end{array}$ & $\begin{array}{l}\text { sprout } \\
\text { Average }\end{array}$ \\
\hline Not chitted ......................... & - & - & - \\
\hline 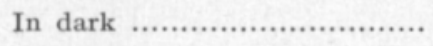 & 1.8 & 2.1 & 2.0 \\
\hline 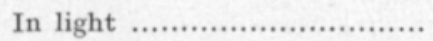 & 1.9 & 2.2 & 2.1 \\
\hline In plastic bags $\ldots \ldots \ldots \ldots \ldots \ldots$ & 1.8 & 2.3 & 2.0 \\
\hline 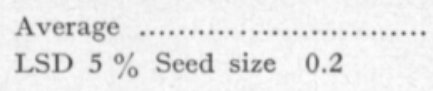 & 1.8 & 2.2 & 2.0 \\
\hline
\end{tabular}

was the same, on an average, with both of the cultivars, but varied annually. Also other annual variations were found. The ratio for Amyla was clearly bigger in the case of the small seed than in the case of the large seed (2.3 and 1.7), for Barima the ratio remained constant (2.1 and 2.0).

A correlation coefficient $\mathrm{r}=+0.75^{* * *}$ was obtained between the number of stems and the number of tubers (Table 11).

Table 11. Tuber number per stem.

\begin{tabular}{|c|c|c|c|}
\hline Chitting method & $\begin{array}{l}\text { Tube } \\
\text { Large seed }\end{array}$ & $\begin{array}{l}\text { number per } \\
\text { Small seed }\end{array}$ & $\begin{array}{l}\text { stem } \\
\text { Average }\end{array}$ \\
\hline Not chitted ........................ & 1.9 & 2.3 & 2.1 \\
\hline 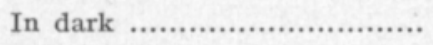 & 1.8 & 2.2 & 2.0 \\
\hline 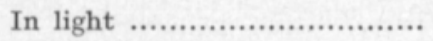 & 1.8 & 2.2 & 2.0 \\
\hline In plastic bags...$\ldots \ldots \ldots \ldots \ldots \ldots$ & 1.8 & 2.1 & 2.0 \\
\hline $\begin{array}{l}\text { Average } \\
\text { LSD } 5 \% \text { Seed size } 0.1\end{array}$ & 1.8 & 2.2 & 2.0 \\
\hline
\end{tabular}

Small seed produced more tubers per stem than large ones (cf. TINGEY and Stewart 1928, Svensson 1962, Pätzold 1964). According to Moorby (1967) this is not the case when equal sized sprouts of various seed sizes are used with adequate spacing. The ratio varied annually $(1.7-2.3)$ and changed during the growing season $(1.9-1.9-2.2)$. 
Several of the tirst order interaction effects were significant. In two years there was a reversed difference between the cultivars. Their reactions to the method of chitting varied irregularly. Correspondingly the number of tubers per stem of the cultivars varied irregularly during the growing season. A difference between the tuber sizes could be noticed each year. The difference between the lifting times varied to some extent annually. Some second order interaction effects also indicated the unbalanced ratio between the numbers of stems and tubers.

Tuber yield

Tuber yield per plant varied depending on seed size (cf. TINGEY and STEWART 1928, Roer 1955, Svensson 1961, Dambroth and Pätzold 1969, Enge 1970, SvensSON and CARLSSON 1972), but in these trials the variation was independent of the chitting method (cf. KRUG and Pätzold 1968, Andersson 1972) (Tables 1 and 12).

Table 12. Tuber yield per hill, g.

\begin{tabular}{|c|c|c|c|c|c|c|}
\hline \multirow[b]{2}{*}{ Chitting method } & \multicolumn{3}{|c|}{ Averages of three liftings } & \multicolumn{2}{|c|}{ Autumn lifting } & \multirow[b]{2}{*}{ Average } \\
\hline & Large see & mall seed & Average & Large seed & Small seed & \\
\hline Not chitted .................. & 497 & 421 & 459 & 779 & 694 & 736 \\
\hline In dark ......................... & 529 & 441 & 485 & 749 & 685 & 717 \\
\hline In light...$\ldots \ldots \ldots \ldots \ldots \ldots$ & 538 & 452 & 495 & 736 & 693 & 715 \\
\hline In plastic bags .............. & 531 & 444 & 488 & 730 & 674 & 702 \\
\hline Average..................... & 524 & 439 & 482 & 748 & 686 & 717 \\
\hline
\end{tabular}

The interaction effect seed size $\times$ chitting method was not significant but chitting affected the yield of both large and small tubers on average in the same way. The tuber yield varied annually $(423-598 \mathrm{~g})$, and it also changed during the growing season $(230-498-717 \mathrm{~g})$.

There were many significant first order interactions. The difference in yield varied annually between the cultivars, large seed produing a larger yield each year. The development of the yield during the growing season also varied annually, but the trend remained the same.

The yield of Barima was more dependent on tuber size than that of Amyla (Amyla 509 and $440 \mathrm{~g}, 14 \%$, Barima 539 and $439 \mathrm{~g}, 19 \%$ ). Chitting clearly increased the yield of Amyla, but had a varying effect on the average yield of Barima. The second order interaction cultivar $\times$ seed size $\times$ chitting showed that the chitting of both seed sizes of Amyla resulted in a clear yield increase, while in the case of Barima, the two seed sizes reacted differently, the small seed showing a better result. The development of the yield of an early cultivar, Barima, was clearly faster than that of Amyla (cf. Emilsson 1950). The development of the yields of large and small seed tubers seemed to differ (Table 12, Figure 4). 


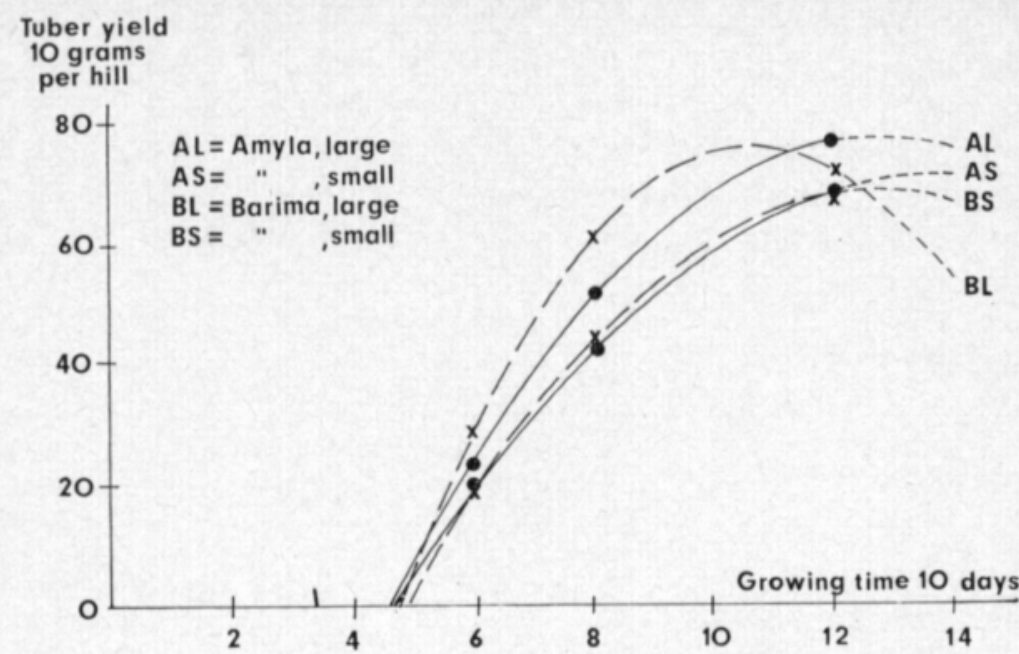

Figure 4. The relation of yield development to seed size.

AL $y=-114.1+30.1 x-1.18 x^{2}$
AS $y=-89.6+23.3 x-0.84 x^{2}$
BL $y=-170.4+46.2 x-2.16 x^{2}$
BS $y=-107.2+27.6 x-1.08 x^{2}$

Large seed tubers had a faster but also a shorter cycle of yield production (see development of the haulms, Figure 3). This difference did not, however, appear each year and only with Barima. The chitting method also affected the rate of yield development (Table 12, Figure 5). Efficient chitting accelerated growth, but also stopped it earlier than in the case of unchitted seed (cf. Toosey 1963, KRUG and PÄTzold 1968). The cultivars reacted in different ways.

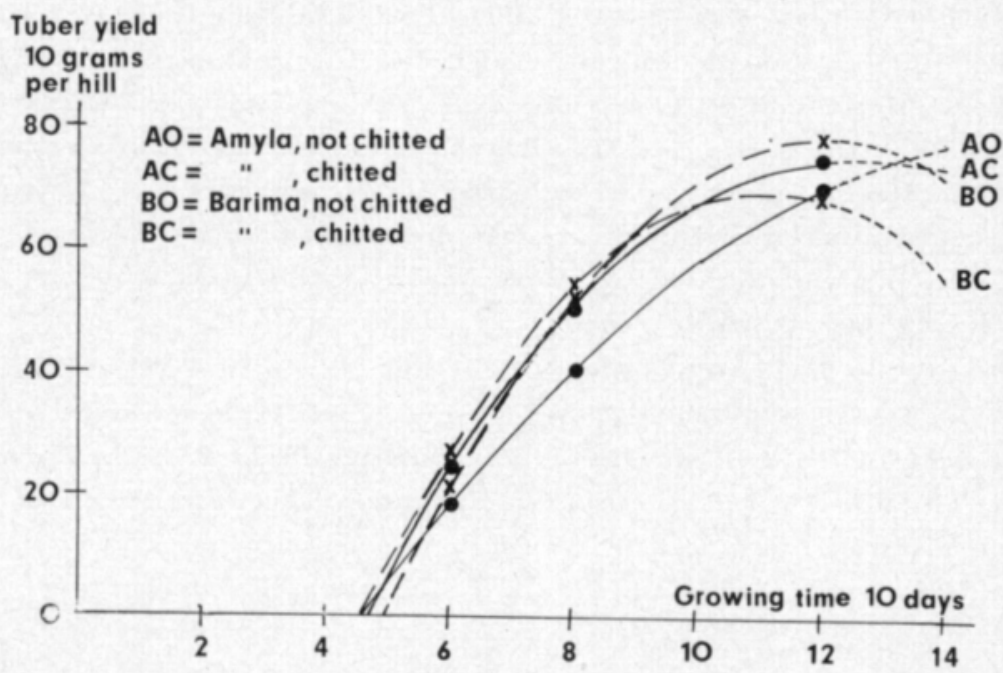

Figure $\Sigma$. Ih 3 relations of yield development to chitting.
$\wedge O \mathrm{y}=-81.4+20.4 \mathrm{x}-0.65 \mathrm{x}^{2}$
AC $y=-109.5+29.0 x-1.14 x^{2}$
BO $\mathrm{y}=-153.0+38.2 \mathrm{x}-1.58 \mathrm{x}^{2}$
BC $y=-140.3+38.0 x-1.72 x^{2}$ 
In order to illustrate tuber size the percentage of large tubers (over $30 \mathrm{~mm}$ ) was determined. It varied depending on the method of chitting, but not on seed size (Tables 1 and 13).

Table 13. Proportion of large tubers.

\begin{tabular}{|c|c|c|c|}
\hline Chitting method & $\begin{array}{r}\text { Tubers } \\
\text { Large seed }\end{array}$ & $\begin{array}{l}\text { pver } 30 \mathrm{~mm} \% \\
\text { Small seed }\end{array}$ & Average \\
\hline 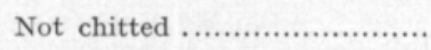 & 76 & 77 & 76 \\
\hline 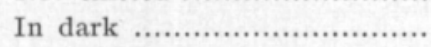 & 87 & 86 & 86 \\
\hline In light & 87 & 88 & 87 \\
\hline 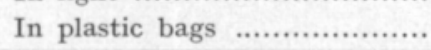 & 88 & 87 & 87 \\
\hline $\begin{array}{l}\text { Average ........................................ } \\
\text { LSD } 5 \% \text { Chitting } 5\end{array}$ & 84 & 85 & 84 \\
\hline
\end{tabular}

Chitting increased the proportion of large tubers in the same way independently of seed size (cf. Emilsson 1950). The proportion of large tubers varied annually $(80-88 \%$ ) and was dependent on the cultivar (Amyla $81 \%$, Barima $88 \%$ ). During the growing season the number of large tubers increased $(74-86-93 \%)$. The tuber size increasing effect of chitting appeared each year although to varying extents. In the case of Amyla the differences caused by the chittings were much bigger $(69-83-85-85 \%)$ than with Barima $(83-90-90-89 \%)$. In the tuber size of Amyla and Barima there appeared a difference each year, although the amount of the difference varied. The proportion of large tubers increased each year towards the end of the growing season, although at different rates. The tuber size of Amyla was remarkably small at the beginning of the growing season (Amyla $64-89-90 \%$, Barima 84-84-96 $\%$ ). The method of chitting also affected the development of the tuber size in that chitting increased the tuber size considerably only in the early lifting $(53-81,85-87$, and $90-94 \%)$, and mainly in the case of Amyla (variety $\times$ chitting method $\times$ lifting time).

Of the significant second order interaction effects that of cultivar $\times$ seed size $\times$ lifting time is worth mentioning. It indicates that the large seed of Barima produced in early liftings more large tubers than did the small seed. The situation was reversed with Amyla. There was no difference between the tuber sizes in the other liftings.

\section{Starch content}

The starch content of the tubers in the autumn lifting depended slightly on seed size, but not on the method of chitting (cf. LäHDE 1943, EMILssoN 1950) (Tables 1 and 14). 
Table 14. Starch content in autumn lifting.

\begin{tabular}{|c|c|c|c|}
\hline \multirow{2}{*}{ Chitting method } & \multicolumn{3}{|c|}{ Starch content } \\
\hline & Large seed & Small seed & Average \\
\hline Not chitted ......................... & 14.6 & 14.6 & 14.6 \\
\hline 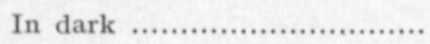 & 14.6 & 15.0 & 14.8 \\
\hline 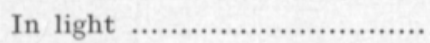 & 14.8 & 15.0 & 14.9 \\
\hline In plastic bags .................... & 14.3 & 15.0 & 14.6 \\
\hline $\begin{array}{l}\text { Average ...................................... } \\
\text { LSD } 5 \% \text { Seed size } 0.3\end{array}$ & 14.6 & 14.9 & 14.7 \\
\hline
\end{tabular}

The starch content varied annually $(13.4-16.4)$ and was dependent on the cultivar (Amyla 17.1, Barima 12.4). Small seed tubers, however, produced a higher starch content only in two years out of four (year $\times$ seed size). The small seed of Barima produced a higher starch content than the large one (12.1 and $12.7 \%$ ), Amyla showed no differences (17.0 and $17.1 \%$ ). The difference in the starch content between the cultivars occurred every year although it tended to vary. Chitting increased the starch content of Amyla (16.8-17.1) but not that of Barima $(12.5-12.4)$.

No significant second order interaction effects appeared.

\section{Tuber blight}

In autumn liftings observations of tuber blight showed differences between the seed sizes (Tables 1 and 15 ).

Table 15. Blight infected tubers in autumn lifting.

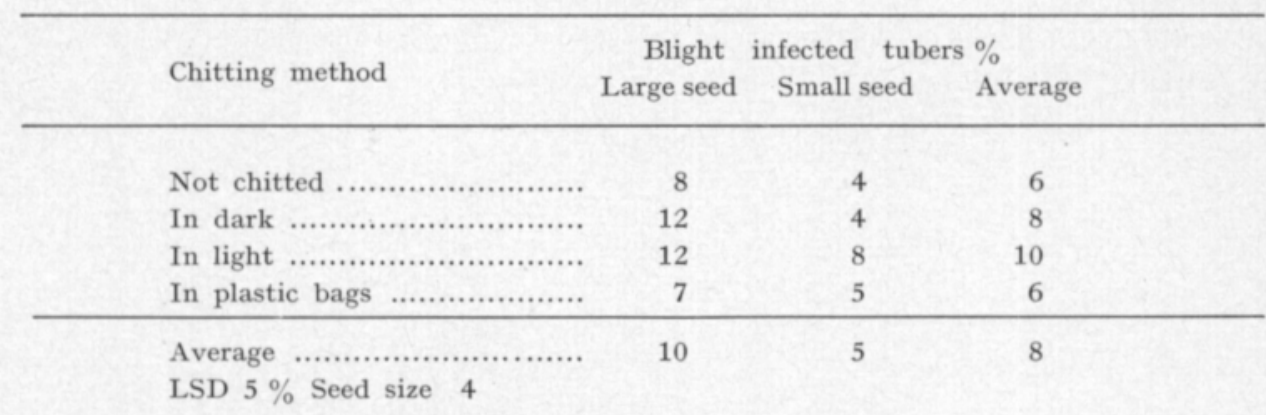

In the yield from large seed tubers there appeared twice as many blight infected tubers as in the yield from small seed. The differences between the chitting methods were not significant. The interaction effect seed size $\times$ chitting method was not significant. As had been supposed, the blight infection varied annually (1-15 per cent) and was dependent on the cultivar (Amyla 2, Barima 13 per cent). Annual variation was noticed as to cultivar and seed size. However, the trend was each year in accordance with the main effect. Concerning the interaction effect cultivar $\times$ seed size it appeared that the large seed of Barima produced most blighted tubers (Amyla 2 and $2 \%$, Barima 17 and $8 \%$ ). In case of Barima the slight interaction effect cultivar $\times$ chitting method 
proved that chitting increased blight infection. Some second order interaction effects further indicated the annual variation.

Scab

Scab analyses of autumn harvests showed differences between the chitting methods (Tables 1 and 16).

Table 16. Scabbiness of tubers in autumn lifting $(0=$ no scab, $100=$ fully scabbe 1$)$.

\begin{tabular}{|c|c|c|c|}
\hline Chitting method & $\begin{array}{l}\text { Scabbiness } \\
\text { Large seed }\end{array}$ & $\begin{array}{l}\text { of tubers } \\
\text { Small seed }\end{array}$ & $\begin{array}{l}0-100 \\
\text { Average }\end{array}$ \\
\hline Not chitted $\ldots \ldots \ldots \ldots \ldots \ldots \ldots \ldots \ldots \ldots \ldots \ldots \ldots \ldots$ & 16 & 14 & 15 \\
\hline 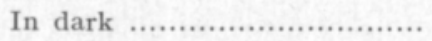 & 11 & 13 & 12 \\
\hline 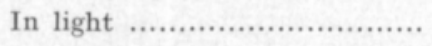 & 11 & 9 & 10 \\
\hline In plastic bags $. . . \ldots \ldots \ldots \ldots \ldots . . . . . . . .$. & 11 & 14 & 13 \\
\hline Average $5 \%$ Chitting 3 & 12 & 13 & 12 \\
\hline
\end{tabular}

Chitting reduced scab. Scabbiness varied annually $(9-17)$ and depended on the cultivar (Amyla 16, Barima 9).

\section{Discussion}

Comparison between the two seed sizes of Amyla and Barima proved that there was a considerable difference between the cultivars in the number of sprouts. In addition, in the case of Amyla the number of sprouts clearly varied more with the seed size. Therefore the difference in the number of sprouts per tuber was the greater the larger the seed tubers of the cultivars were (Figure 1).

Seed size affected the growth and the yield of the potato in many respects (Table 17).

Table 17. The effects of seed size and chitting on the growth and yield of potato plants.

\begin{tabular}{|c|c|c|c|c|c|c|c|c|c|c|c|c|}
\hline & 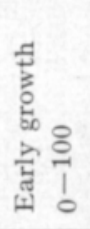 & 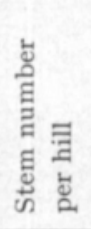 & 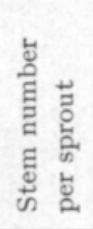 & 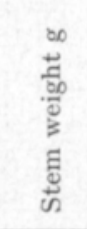 & 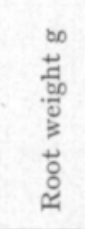 & 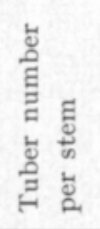 & 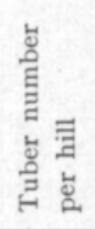 & 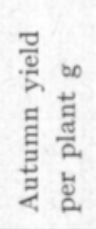 & 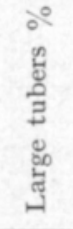 & 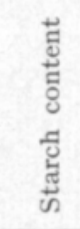 & 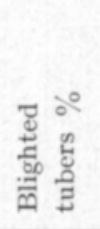 & 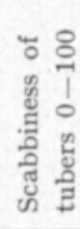 \\
\hline Large seed ... & 46 & 7.6 & 1.0 & 358 & 82 & 1.8 & 13.4 & 748 & 84 & 14.6 & 10 & 12 \\
\hline Small seed ... & 38 & 4.8 & 1.0 & 277 & 54 & 2.2 & 10.5 & 686 & 85 & 14.9 & 5 & 13 \\
\hline Difference \% & -17 & -37 & ns & -23 & -34 & +22 & -22 & -8 & ns & +2 & -50 & ns \\
\hline Not chitted.. & 33 & 6.6 & - & 350 & 74 & 2.1 & 13.6 & 736 & 76 & 14.6 & 6 & 15 \\
\hline Chitted ........ & 45 & 6.1 & - & 307 & 65 & 2.0 & 11.4 & 711 & 87 & 14.8 & 8 & 12 \\
\hline Difference \% & +36 & -8 & - & -12 & -12 & ns & -16 & -3 & +14 & ns & ns & -20 \\
\hline
\end{tabular}


From all seed tubers the stem numbers were proportional to the number of viable sprouts. The early development of plants from small seed tubers was slower, but the growth of the small seed plants continued longer (Figure 3) (cf. Moorby 1967). The weight of the roots showed a greater difference than did that of the stems. Small seed produced more tubers per stem than large seed, and this resulted in a smaller decrease of tuber number per hill. The difference in yield was still smaller than the difference between the tuber numbers, although no distinct difference in the tuber size of the yield existed (cf. Tingey and Stewart 1928, Janda 1970). The probable explanation may be found in a decreased inter-plant competition in the case of small seed and in the fact that the yield from smaller seed took longer to grow because of the difference in the growth rhythm. Probably for the same reason the starch content of the yield from small seed was slightly higher. Small seed produced healthier yield, which may be due to the better tuber distribution in the ridge (LACEY 1966). These results can be partly interpreted as being caused by the different spacing per stem (PÄTzOLD 1964), but even considering this, they indicate a real physiological difference between large and small seed tubers (cf. Bremner and El Saeed 1963, Moorby 1967). The advantage of large seed tubers is the greater number of sprouts per tuber, whereas small seed possesses more sprouts per a given weight. By employing small seed a more efficient usage of seed is obtainable in conditions where the delayed growth rhythm of small seed is not a disadvantage (cf. Bremner and El SAEed 1963, Moorby 1967).

The cultivars used in this experiment reacted differently to seed size on several points (interaction effects cultivar $\times$ seed size). As pointed out earlier the dependence of the number of sprouts on seed size differed in the cultivars studied. Differences observed in the early growth of the plants indicated a variation in the viability of the sprouts in the different seed sizes of the cultivars. The difference in the number of sprouts is also reflected in the number of stems and the weight of the haulms and roots, although in the latter case the percentage difference was equal in both of the cultivars. Also the number of tubers per plant varied in the same proportion in both of the cultivars. The seed size of the cultivars also affected the amount of yield differently, the difference being larger with Barima. The differences in quality are partly related to differences in earliness and resistance to diseases.

The effects of the chittings were also clear. As only slight differences appeared between the chitting methods used, the average values of chitted tubers are used in Table 17. Chitting accelerated the early growth of the plants, the average weight of the haulms nevertheless remained lower since chitting accelerated the growth rhythm. The difference in haulm weight was partly due to a reduction in the number of stems caused by chitting. In the same way the number of tubers was also reduced. However, chitted seed produced a large tuber yield, excluding the autumn lifting of Barima. Tuber size increased somewhat, the difference in the starch content was not significant. The reduction of scab may be due to the accelerating effect of chitting on growth rhythm. Toosey (1963), and KRUG and PäTzOLD (1968) achieved similar results in experiments with chitting. 
To some extent the cultivars used reacted differently also to chitting. The numbers of stems and tubers decreased especially with Barima, the yield of the maincrop cultivar Amyla increased as did the tuber size. The differences in the starch content variation are most likely due to the different earliness of the cultivars.

Regarding possible differences in the reaction of large and small tubers to chitting these are shown in the interaction effects of seed size $\times$ method of chitting. Only slight differences occurred: chitting reduced to a greater extent the number of stems and the weight of roots of large tubers, as well as the number of tubers per hill produced from large seed. These differences are reflected differently in the yield results, depending on the cultivar. However, the chitting of small seed is likely to be more important because of the slower growth rhythm of plants from small seed.

According to the results obtained, the use of small seed seems profitable. Small seed tubers produce more yield for a weight unit than large ones, as under favourable growing conditions the number of viable sprouts is the decisive factor (BLEASDALE 1965). Less stems per seed tuber are produced from small seed with the smaller number of sprouts, nevertheless relatively more new tubers are formed because of a reduction in inter-plant competition. This is probably also the case when the density of the stands is the same. With small seed the stems are more evenly distributed in the ridge which reduces competition between the plants.

The growth rhythm of large and small seed connected with chitting varies sufficiently to warrant discussion of the suitability of the alternatives for different production purposes. In the production of early potatoes large, efficiently chitted seed (physiologically old seed) seems to be appropriate as it guarantees fast early growth and an early yielding. On the other hand, when an ample autumn yield is desired, smaller seed (physiologically young seed) seems appropriate at least under favourable conditions, and chitting can be recommended for most varieties (cf. Toosey 1963, KRUG and Pätzold 1968). In Finland chitting usually gives good results except in the earliest varieties grown for seed or maincrop purposes in southern parts of Finland. This is due to the short growing season and the lateness of the cultivars generally grown (LÄHDE 1943). As chitting affects both the growth rhythm and the density of the stand it is possible to adapt the chitting according to the characteristics of the cultivars and the time of the harvest.

The appropriate plant density in various growing conditions is a problem when seed tubers of varying sizes and pre-treatments are used. In order to estimate the ideal density, Figure 1 may be used: when the average weight of the seed tubers $(x)$ is known the number of stems can be estimated according to this figure. However, the relationship is far from accurate if the coefficient of the cultivar (n) is not known. A more exact result is achieved when the average number of viable sprouts per seed tuber is counted at the time of planting. On an average, each sprout produces one stem. 


\section{REFERENCES}

ANDersson, S. 1972. Förgroning av utsädespotatis i norra Sverige. Lantbr.högsk. Medd. A 171: $1-27$.

Birecki, M. \& Roztropowicz, S. 1963. Studies on seed potato size and productivity. Eur. Potato J. 6: 1-13.

Bleasdale, J. K. A. 1965. Relationships between set characters and yield in maincrop potatoes. J. Agric. Sci. 64: $361-366$.

BRemner, P. M. \& El SaeEd, A. K. 1963. The significance of seed size and spacing. The Growth of the Potato. p. 267-280. London.

Dамвroth, M. \& Pätzold, C. 1969. Mineraldüngung, Erntetermin, Sorte, Standraum und Pflanzgutgrösse in ihrem Einfluss auf die Ertagsstruktur der Kartoffel. Landbauforschung Völkenrode 19,1: 29-38.

DENT, J. B. \& HALKon, W. S. 1969. Influence of time of sprouting and weight of stored seed tubers on the production of sprouts and shoots. Eur. Potato J. 12: 49-58.

EmiLsson, B. 1950. Inverkan på avkastningen av utsädespotatisens förgroning. Kungl. Lantbr. akad. Tidskr. 89: 315-339.

ENGE, R. 1970. Virkningen av nitrogen, settepotetstørrelse og setteavstand på avlinga av tidligpoteter. Meld. Norg. Landbr.høgsk. 49: 1-12.

FrENCH, G. 1958. Seed cutting and handling. Potato Handbook 1958: 39-48.

Holmes, J. C. 1966. Seed size and spacing for seed and potato crops. Scott. Agric. 45: 176-180.

JANDA, R. 1970. Wertigkeit der Sortiergrössen bei Pflanzkartoffeln. Kartoffelbau 21: 125-126.

KIvi, E. \& VARIS, E. 1965. Tammiston ja Anttilan sääoloista. Siemenjulkaisu 1965: 228-235.

KrUG, H. \& PätzoLD, C. 1968. Neue Forschungsergebnisse über das Vorkeimen von Kartoffelpflanzgut. Schriftenreihe des AID. Heft 150: 1-64.

LACEY, J. 1966. The distribution of healthy and blighted tubers in potato ridges. Eur. Potato J. 9: $86-98$.

LÄHDE, V. 1943. Siemenmukulain idätyksen vaikutuksesta perunan satoon. Valt. Maatal.koetoim. Tied. 193: 1-14.

Moorby, J. 1967. Inter-stem and inter-tuber competition in potatoes. Eur. Potato J. 10: 189205.

PÄtzold, C. 1964. Untersuchungen zum Reihenabstand im Kartoffelbau. II. Pflanzenentwicklung. Eur. Potato J. 7: 1-12.

RaIDt, W. 1961. Neues, verbilligtes Vorkeimverfahren. Kartoffelbau 12: 234-235.

REKUNEN, M. 1970. Sääoloista Hankkijan kasvinjalostuslaitoksen koepaikoilla vv. 1965-1969. Siemenjulkaisu 1970: $145-149$.

RoER, L. 1955. Forsøk med forskjellige settepotetstørrelser og ulike setteavstander. Forskn. Fors. Landbr. 6: $17-37$.

Svensson, B. 1961. Matpotatisens kvalitet. St. Jorbr.förs. Medd. 126: 1-37.

,- 1962 . Some factors affecting stolon and tuber formation in the potato plant. Eur. Potato J. 5: $28-39$.

-1 - 1966. Seed tuber - stand - yield. Properties and relationships. Växtodling 21: 1-86.

- - \& CARLsson, H. 1972. Inverkan av sättstorlek och sättavstånd på knölskörden av potatis. Lantbr. högsk. Medd. A 166: 1-25.

Tingey, D. C. \& Stewart, G. 1928. Effect of size of seed set on yield and on certain other characters in potatoes. J.' Amer. Soc. Agr. 20: 710-721.

Toosey, R. D. 1962. Influence of pre-sprouting on tuber number, size and yield of King Edward potatoes. Eur. Potato J. 5: 23-27.

- 1963. The influence of sprout development at planting on subsequent growth and yield. The Growth of the Potato. p. 79-94. London, 


\title{
Mukulakoon ja idätysmenetelmän vaikutus Amyla- ja Barima-perunan kehi- tykseen ja sadonmuodostukseen
}

\section{EERO VARIS}

\author{
Hankkijan kasvinjalostuslaitos, Anttilan koetila, Hyrylä
}

Tutkimuksessa selvitettiin kahden siemenmukulakoon ( $34 \mathrm{~g}$ ja $89 \mathrm{~g}$ ) vaikutusta perunan kasvuun ja sadonmuodostukseen erilaisia idätystapoja käyttäen. Koelajikkeet olivat Amyla ja Barima.

Siemenmukulan koko vaikutti monella tavalla perunan kasvuun, mutta muutokset eivät olleet suoraan verrannollisia siemenmukulan painoon. Pientä siementä käytettäessä varsiston alkukehitys oli hitaampaa, versojen määrä pienempi, varsiston ja juuriston paino pienempi. Mukulamäårä/kasvi oli pienempi, mutta suhde mukuloita kpl/verso suurempi. Sato siemenmukulaa kohti oli $16 \%$ pienempi. Sadon tärkkelyspitoisuus oli pientä siementä käytettäessä hiukan korkeampi ja ruttoisuus pienempi.

Kasvurytmissä oli eroa sikäli, että isosta siemenestä kehittyneet kasvit kasvoivat nopeammin ja niiden varsiston ja juurien paino aleni syksyllä enemmän. Myös mukulasato oli alussa selvåsti suurempi kuin pienellä siemenellä, mutta ero tasoittui syksyllä aikaisella Barima-lajikkeella.

Idätys aiheutti siemenmukuloissa keskimäärin $5 \%$ :n painohäviön lisääntymisen, mikä tosin vaihteli riippuen idätystavasta. Idätys nopeutti alkukehitystä, vähensi versojen määrää, alensi varsiston ja juurien painoa sekä vähensi mukulalukua/kasvi. Sadon ja tärkkelyspitoisuuden nousut eivät ollet keskimäärin merkitseviä, mutta olivat riippuvaisia nostoajasta. Isojen mukuloiden määrä lisääntyi ja rupisuus väheni idätystä käytettäessä.

Idätys nopeutti kasvurytmiä ja sadon muodostusta, mutta lopetti varsiston ja sadon lisäkasvun aikaisemmin.

Idätyksen vaikutukset isojen mukuloiden kasviopillisiin ominaisuuksiin olivat suuremmat kuin pieniin mukuloihin. Vaikutus satoon oli keskimäärin samanlainen, tärkkelyspitoisuus nousi vain pienillä mukuloilla. Idätyksen vaikutus oli sitä selvempi, mitä tehokkaampaa se oli.

Amyla ja Barima reagoivat monessa suhteessa eri tavalla sekä siemenkokoon että idätykseen. Erot johtuivat toisaalta erilaisesta silmujen määrästä, toisaalta lajikkeiden aikaisuuserosta.

Tulosten perusteella päådytään suosittelemaan varhaisperunan tuotannossa isohkon hyvin idätetyn siemenen käyttöä. Talviperunan ja siemenperunan viljelyssä voidaan käyttää myös pientä siementä ja idättää sitä harkiten lajikkeen aikaisuuden ja kasvuolojen edullisuuden mukaan. Kuitenkin pienen siemenen kunnollinen idätys näyttää olevan tärkeämpää kuin ison johtuen pienen siemenen hitaammasta kehitysrytmistä. 